\title{
ESL LEARNERS' LANGUAGE ERRORS IN A REFLECTIVE WRITING ASSESSMENT
}

\author{
Nor Syamimi lliani CHE HASSAN*1 \\ Nor Hairunnisa MOHAMMAD NOR ${ }^{2}$ \\ Rohazlyn ROSLY ${ }^{3}$ \\ Wan Nuur Fazliza WAN ZAKARIA ${ }^{4}$ \\ Akademi Pengajian Bahasa UiTM Cawangan Kelantan \\ Bukit IImu, 18500 Machang, Kelantan. \\ ${ }^{1}$ syami@kelantan.uitm.edu.my \\ ${ }^{2}$ nisa032@kelantan.uitm.edu.my \\ ${ }^{3}$ rohazlyn@kelantan.uitm.edu.my \\ 4wfazliza@kelantan.uitm.edu.my
}

Manuscript received 15 March 2019

Manuscript accepted 17 May 2019

*Corresponding author

https://doi.org/10.33736/ils.1291.2019

\begin{abstract}
Perceived as one fundamental element in language learning, grammar is reckoned important in ESL writing. ESL learners need to master the knowledge of how to transfer grammatical concepts into their ESL composition. However, Malaysian learners of English often repeat errors in writing which they cannot even recognise. The current study draws attention to the occurrences of language errors and examines their sources in Malaysian ESL learners' writing. The participants were 40 students in their Semester 2 of diploma level. Each student was to produce two essays of 100-word length. Each essay was first examined before language errors were identified and coded based on the parts of speech: Nouns, Verbs, Adjectives, Adverbs, Articles, Pronouns, Prepositions, Adverbs, Conjunctions and Determiners. For each type of error, the sources were categorised based on interlingual and intralingual sources. A total of 258 errors were identified and the most frequent language errors was verb errors while the least was determiner errors. The result revealed that the most dominant errors were caused by intralingual sources. This study would greatly help teachers to establish better curriculum and select materials to facilitate students in learning English and develop them as proficient learners who can self-correct language errors.
\end{abstract}

Keywords: Error analysis, interlingual errors, intralingual errors, writing, ESL 


\section{Introduction}

Complex and challenging in nature, writing is implicitly fathomed as the toughest language skill to come to grips with. After more than 10 years of learning English at both primary and secondary levels, these ESL learners still make various kinds of errors, not only in their choice of words and spelling but also in the use of grammar. The earlier proponent of Error Analysis (EA), Corder (1967), affirmed that errors are made by beginners of second or other languages learners who do not yet have a full command of the target language system. In relation to this, Putri and Dewanti (2014) claimed the learners cannot avoid grammatical errors in writing; they do not attend to those errors, and they do not know how to correct those errors.

Perceived as one fundamental element in language learning, grammar is deemed important in the process of writing. In view of this language learning issue, ESL learners need to master the knowledge on how to transfer concepts of English grammar into their writing composition. This is pertinent in order to minimise the number of language errors in the L2 learners' writing. Additionally, Singh, Singh, Razak, and Ravinthar (2017) stated that learners who understand grammatical concepts are at an advantage as English language has been made compulsory in our curriculum, and more importantly the toughest language skill, writing, is emphasised compared to listening, speaking and reading skills. In relation to this, Al-Sawalha and Chow's (2012) findings showed that learners' inabilities to perform their planning, editing and revising activities can be attributed to their lack of linguistic skill or vocabulary knowledge. This echoes Gustilo and Magno (2015) who reported that L2 learners' writing performance is directly dependent on their linguistic knowledge, hence urging teachers to put primary focus on this knowledge. Thus, it is evidently confirmed that inadequate linguistic knowledge or insufficient language competence negatively affect the quality of L2 writing on top of their English grades (Pae, 2018; Watcharapunyawong \& Usaha, 2012).

Analysis of errors is crucial due to its noteworthy contribution in the field of language learning and teaching. By providing an illustration of the common language errors made by these learners in writing, it alerts them to the types of common errors they frequently make. Instantaneously, language teachers will understand their students' errors, and this aids them in building educational techniques to improve students' level of English proficiency (Abushihab, 2014).

\section{Problem Statement}

Issues of ESL learners struggling to write well has long been a matter of concern in Malaysia. This is evident as Nunan (1999) asserts that ESL learners at the beginning strive to write in the target language, the one that is dissimilar from their first language; the task is even more challenging when these learners are expected to compose a well-developed and seemingly effortless writing. Several factors including L1 interference and linguistic incompetence predominantly in the concepts of grammar, make it difficult for the learners to write satisfactorily. This is supported by Ghabool, Mariadass, and Kashef (2012) who agree that the main cause of difficulties in accomplishing any written tasks is lack of English language proficiency. 
Therefore, it is the learners' mother tongue and their incompetency in the use of the target language that lead them to more complicated problems when they are asked to produce any forms of writing.

Meanwhile, learners' behaviours and viewpoints concerning the target language contribute to writing problems too. One other study conducted by Ismail, Elias, Albakri, Perumal, and Muthusamy (2010) found that the writing apprehension level and attitudes of ESL tertiary students of MARA University of Technology played significant roles in determining students' writing performance; many were found apprehensive and have negative perceptions towards writing, thus impinging on their academic writing qualities. In relation to this, essential ingredients such as knowledge bases, attitudes, apprehension, strategy use, and self-efficacy are evident in shaping L2 writers' behaviours. These according to Chan and Abdullah (2004) are affect in writing which are deemed important in the development of effective writing.

Learners of English every so often repeat errors in writing which they cannot even recognise. The ones who can only help them to locate those errors are their language teachers and researchers. Additionally, the distinctive traits of errors which cannot be executed by self-correcting and is the result of a learner's target language inadequacy explain that errors are systematic. Hence, the gap between the learners' knowledge of the target language and the need of language use support the relevance of EA (Abushihab, 2014).

Low proficient ESL students (those whose school was categorised at credit 6, the second lowest level, based on Malaysian school ranking system) who possess limited vocabulary knowledge and grammatical incompetency have to be drawn against great challenges in writing (Sovakandan, Jaganathan, \& Husain, 2018). This is in agreement with Mohamed and Darus's (as cited in David, Azman, \& Tan, 2018) claim that the contributing factors to L2 learners' difficulties in performing written tasks are psychological, linguistic and cognitive aspects. In terms of the linguistic aspect, an L2 learner is required to construct grammatically correct sentences and to form the organisation of the points appropriately.

Errors on the use of nine parts of speech attracted the researchers the most because they are the basis for sentence construction of English language. The current study therefore, draws attention to the occurrences of language errors and further examines their sources in Malaysian ESL learners' writing. Thus, this study aims to achieve the following objectives:

1) To examine the frequency of language errors in ESL learners' written assessment.

2) To investigate the types of language errors in the writing of ESL learners.

\section{Error Analysis in ESL Studies}

Error analysis studies are not something new in the field of second language acquisition and Vásquez (2007) also states that error analysis is the central element in language teaching. By knowing common errors that learners always do, it helps to reorganise teachers' viewpoints and adapt their teaching methods to address the learners' gaps. There are two significant methods to study errors committed by 
learners; contrastive analysis which was introduced by Lado (1957) and error analysis by Corder (1967). However, the latter only emerged after the shortcomings of contrastive analysis had been pointed out by many researchers during that time.

In conducting error analysis research, there are five systematic procedures which are commonly practised by researchers and teachers (Corder, 1967). The first procedure is collecting samples from language learners. Once done, the errors in the samples are identified and then carefully described before they are categorised based on their nature and causes. Lastly, the severity of the errors is also assessed by the researchers or teachers.

It is of paramount importance to identify learners' recurring errors critically because the errors made will act as indicators on how much the learners have learned and also their progress in acquiring a language (Brown, 2000; Corder, 1967; Ringbom, 1987). Once the errors have been identified then, the sources which contribute to the errors would be known. This is where Richards (1971) proposed three sources of errors. The first source is interference errors where these errors are the results of elements used in one's language while speaking or writing. Secondly, intralingual errors and these errors are the reflections of general characteristics of rule learning like faulty generalisation, incomplete application of rules, and failure to understand conditions in which rules apply. The third source of errors is developmental errors. These errors occur when hypothesis for the target language is drawn using learners' inadequate experiences in the target language.

However, the differences between the definitions given to the three sources (interference, intralingual and developmental) are fuzzy. Hence, in 1974, Richards narrowed the sources into two sources only. The first one is named interlingual source where mother tongue interference is claimed to be the cause of errors. Selinker (1974) then described interlingual errors as negative interference from the learners' mother tongue habits. For example, direct translation from their native language in their second language spoken and written work.

After the term interlingual was introduced by Richards (1974), there are numerous studies conducted on this source of errors. For instance, in Ying's study (as cited in Heydari \& Bagheri, 2012), 120 Taiwanese EFL students' essays were scrutinised and the errors made were sorted based on three criteria; overgeneralisation, simplification and language transfer. The result showed that 1,250 errors detected in the essays and language transfer was the highest, 78.9\%. Overgeneralisation was the second, $13.6 \%$ and the lowest error was simplification, $7.5 \%$. Therefore, the findings here suggest that learners make a lot of errors due to language transfer.

In another study by Huang (2006), it is found that the learners' inclination to commit interlingual errors is high and the errors were on mechanics, style and grammar. These errors were transferred from the EFL students' mother tongue. When a learner learns a language, he is fully aware of his mother tongue and that the tendency of transferring what he already knew is very high. It could also be due to the parallel structure of the two languages; where this leads to "positive transfer" or "facilitation". In the case of different structures of the two languages, it would lead to "negative transfer" or "interference" (Wilkins, as cited in Mohideen, 1996). 
For the second source which is intralingual, the errors arise in the second language learning process where learners have not completely mastered the knowledge. Richards (1974) identified four main types of intralingual errors which are overgeneralisation, ignorance of rule restrictions, incomplete application of rules and hypothesis of false concepts. Errors can also transpire due to the difficulty of the language itself. Richards (1974) stated that intralingual errors are produced by the learners that do not reflect the structure of the first language, but overgeneralisation is made based on incomplete exposure to the target language.

There are also numerous studies carried out on intralingual source of errors like the one by Sattayatham and Honsa (2007). They found out that native language has quite a minimal impact on the second language where it affects only 3 to $25 \%$ of such errors but more errors are caused by intralingual sources. Another example comes from Kim (2001). She analysed errors in 30 writing samples of Korean college freshman students who registered for TOEIC class and it was discovered that most of the learners' errors were in the areas of verbs, prepositions, articles, singular/plural agreement, adjectives and conjunctions. These errors were all intralingual and only small instances could be attributed to first language interference. These findings are all parallel with Brown's (1994) claim that second language learners trail similar developmental outlines to children's first language acquisition. From these two different sources of errors, interlingual and intralingual, it can be concluded that second language learners initially produce huge number of interlingual errors. Nevertheless, as they progress in the target language acquisition process, more intralingual errors are portrayed (Brown, 1994).

Based on Corder (1974), error analysis studies could also contribute in three major aspects in second language development. Firstly, it can give various contributions to teachers especially in identifying learners' language acquisition progress. This claim is also in line with Richards (1971) who stated that from the errors analysis studies, teachers can identify areas to focus on in the second language classroom. By having this information, it would greatly help teachers to mould better curriculum and identify resources to assist the second language learning. This is also supported by Vahdatinejad (2008) who stated that from error analyses teachers can determine what learners still need to be taught. Secondly, error analysis studies can also back up researchers in acquiring evidence in language acquisition and the steps taken by learners in language learning stages. Finally, errors can act as a device to assist learners in their language learning process when they receive feedback from teachers on their errors (Alhaisoni, 2012).

\section{Methodology}

A total of 80 students from two classes were selected out of 625 students to participate in the research through a convenience sampling as they were easily accessible by the researchers throughout the course of the research (Etikan, Musa, \& Alkassim, 2016). They were all in their second semester of a diploma program at a Malaysian public university. All the students were of a Malay background, spoke Malay as their first language and English as their second language. They had achieved a passing grade (grade $\mathrm{C}$ and above) in the English subject when they were 
in Semester 1, thus, were able to produce essays written in English. Each student was instructed to produce one essay each and the study collected 80 essays which were written in not more than 100 words. The error analysis was conducted following Corder's (1974) stages of error analysis (Vásquez, 2008). Each essay was first examined before errors in parts of speech were identified. Then, the errors were coded based on the specific parts of speech: nouns, verbs, adjectives, articles, pronouns, prepositions, adverbs, conjunctions and determiners. The study only analysed individual errors made on the selected parts of speech and disregarded any syntactical errors.

\section{Findings and Discussion}

Table 1 shows that 258 errors were identified out of approximately 6,650 words produced by the students. The analysis reveals that verb errors (33.33\%) were the most frequent while errors in the use of determiners $(1.94 \%)$ were the least frequently produced by the students.

Table 1

Types of errors and the frequency of occurrence

\begin{tabular}{lll}
\hline Types of Errors & Frequency & Percentage (\%) \\
\hline Verbs & 86 & 33.33 \\
Nouns & 49 & 18.99 \\
Adjectives & 31 & 12.02 \\
Articles & 29 & 11.24 \\
Pronouns & 28 & 10.85 \\
Prepositions & 18 & 6.98 \\
Adverbs & 6 & 2.33 \\
Conjunctions & 6 & 2.33 \\
Determiners & 5 & 1.94 \\
\hline
\end{tabular}

Table 2 highlights examples of language errors based on the respective categories which have been extracted from students' essays. The analysis discloses that students committed errors most frequently when using verbs. In English, there are different rules for the use of singular and plural verbs, auxiliary verbs and tenses. One reason to explain the occurrence of such errors is differences between verb rules in English and Malay language as Richards (1974) has put forward that L1 interference results in learners' $L 2$ errors. The findings are consistent with Singh et. al. (2017) who found that students often make subject-verb agreement and tense errors in ESL writing. The students in both studies also share the same background as most of them were Malay students and spoke the Malay language as their first language. One of the areas which pose difficulty and confusion to ESL learners is the subject-verb agreement where in the present tense the verb forms to receive inflection are third person singular forms (he/she/it). 
Table 2

Samples of the most frequent and least frequent language errors

\begin{tabular}{|c|c|c|}
\hline $\begin{array}{l}\text { Types of } \\
\text { errors }\end{array}$ & $\begin{array}{c}\text { Extract from students' } \\
\text { essays }\end{array}$ & Correction \& Explanation \\
\hline Verbs & $\begin{array}{l}\text { 1. Most business } \\
\text { transactions were } \\
\text { done via the Internet } \\
\text { in today's digital age. }\end{array}$ & $\begin{array}{l}\text { 1. Most business transactions are } \\
\text { done via the Internet in today's } \\
\text { digital age. } \\
\text { Explanation: 'today' marks that an } \\
\text { action is going on at present, thus, } \\
\text { the verb has to be in the simple } \\
\text { present tense. }\end{array}$ \\
\hline
\end{tabular}

2. Students can recording 2. Students can record lectures using lectures using various applications.

3. I am strongly agree that attitude is an important factor of success.

\section{various applications.}

Explanation: 'can' is a modal verb which must be followed by a baseform verb.

3. I strongly agree that attitude is an important factor of success.

Explanation: 'agree' is a verb used to state one's opinion and does not require a verb-to-be.

Determiners 1. He does not have many energy to carry out the tasks given by his boss.

. He does not have much energy to carry out the tasks given by his boss.

Explanation: The determiner 'many' is used with plural countable nouns. Since 'energy' is uncountable noun hence, the determiner 'much' is used.

2. He only has a little time to enjoy his life.

2. He only has a few time to enjoy his life.

Explanation: The determiner 'a $f^{\prime} w^{\prime}$ is used with plural countable nouns. Since 'time' is an uncountable noun hence, the determiner 'a little' is used.

3. She gets to improve 3. She gets to improve her confidence her confidence in in using English when she speaks using English when she speaks the language to others people that she meets at conferences. the language to other people that she meets at conferences.

Explanation: A determiner 'other' can be used for a noun. As a determiner, 'other' does not have a plural form as in 'others'. Therefore, the correct form for the determiner is 'other'. 
Larsen-Freeman and Celce-Murcia (1999) have identified the typical errors produced by ESL learners in relation to subject-verb agreement. When students become uncertain of the grammatical rules, they tend to simplify and leave the inflection that should appear in the verbs for third-person singular forms. The examples extracted from the students' essays analysed in the study clearly illustrate the claim made by Larsen-Freeman and Celce-Murcia (1999):

\section{Sample 1}

English sentence: Sasha want to protect her mother from his father. (Sasha wants to protect her mother from his father.)

Malay translation: Sasha ingin melindungi ibunya daripada (dianiayai oleh) bapanya.

\section{Sample 2}

English sentence: He also need to stay all day on his wheelchair. (He also needs to stay all day on his wheelchair.)

Malay translation: Dia juga perlu berada di atas kerusi rodanya sepanjang masa.

The sentence begins with Sasha (she) which requires the third-person singular inflection (-s) but the student has omitted the inflection. This is a common error that is produced by ESL learners as English is a subject-prominent language (Ansaldo, 2010) which marks subject-verb agreement while the Malay language which is the students' native language is topic-prominent (Ansaldo, 2010). An example of a subject-prominent Malay sentence given by Ansaldo $(2010$, p. 507$)$ is as follows:

Malay sentence: Dia banyak cantik. (She very pretty)

English sentence: She is very pretty.

Nayan and Jusoff (2009) focused their study only on the use of subject-verb agreement among ESL students and concluded that the errors of English subjectverb agreement were due to students' lack of comprehension of the rule as their L1 (Malay language) does not posit rules in subject-verb agreement.

Although in the study determiners were discovered as the least frequent errors, the errors were reflection of the findings by Marlyna, Tan, and Khazriyati (2007) in which the students also used the wrong form of determiners. As English determiners are used with restriction to the types of nouns (countable and uncountable nouns), Malay students would face difficulties in using the particular word class accurately in writing. While quantifiers also act as determiners they can be placed before a noun, ESL learners must be able to differentiate between quantifiers for countable nouns and uncountable nouns as different rules apply to each of these (Seaton \& Fergusson, 2010). Subramaniam and Khan (2013) identify that English determiners have been classified as the most problematic areas alongside subject-verb agreement and copula be. In the Malay language, the term for determiners is kata bilangan which are categorised in five types: (i) quantifiers 
that denote quantity and are present in cardinal numbers; (ii) quantifiers that indicate indefinite amount; (iii) quantifiers that are cumulative; (iv) quantifiers that indicate separations and (v) quantifiers that indicate fractions (Karim, Farid, Musa, \& Mahmood, 2009). These differences between the rules of both languages pose difficulties to Malay ESL learners and as a result they produce errors as in the following example which was extracted from a student's essay:

English sentence: He does not have many energy to carry out the tasks given by his boss.

(He does not have much energy to carry out the tasks given by his boss.)

Malay translation: Dia tidak mempunyai banyak tenaga untuk

melaksanakan tugasan-tugasan yang diberikan oleh ketuanya.

In the Malay language, the quantifier "many" is equal to "banyak" which is a quantifier that indicates indefinite amount of things and can be used for both countable and uncountable nouns. As a consequence, the student has inaccurately applied his knowledge of L1 rules into the rules for English grammar.

Table 3

Frequency of interlingual and intralingual errors

\begin{tabular}{lccc}
\hline Types of Errors & Frequency & Interlingual errors & Intralingual errors \\
\hline Verbs & 86 & 13 & 73 \\
Nouns & 49 & 18 & 31 \\
Adjectives & 31 & 5 & 26 \\
Articles & 29 & 5 & 24 \\
Pronouns & 28 & 5 & 23 \\
Prepositions & 18 & 8 & 10 \\
Adverbs & 6 & 1 & 5 \\
Conjunctions & 6 & 4 & 2 \\
Determiners & 5 & 0 & 5 \\
\hline Total & 258 & $59(22.87 \%)$ & $199(77.13 \%)$ \\
\hline
\end{tabular}

Richards (1974) proffered the idea that two main sources of errors are identifiable as interlingual errors engendered by L1 interference and intralingual errors which result from the lack of $L 2$ knowledge. Based on the analysis of students' essays, the researchers identified the produced errors further than word-class errors. It is imperative to diagnose students' sources of errors as either interlingual (caused by first-language transfer) or intralingual (conflicting information of the second language) (Kaweera, 2013) so as to accommodate teaching content to students' actual deficiencies in grammatical knowledge and needs. Examples of interlingual and intralingual errors are as follows:

Interlingual error: People who are on diet should choose meals based on pyramid food.

Malay translation: Mereka yang berdiet perlu memilih hidangan berpandukan 


\section{piramid makanan.}

Intralingual error: Women should be grateful and proud of their self. (Women should be grateful and proud of themselves.)

Malay translation: Wanita perlu bersyukur dan berasa bangga dengan diri sendiri.

This in-depth analysis which was conducted by identifying the similarities and differences between grammatical errors of English and Malay language has revealed that the dominant errors were caused by students' lack of English grammatical knowledge. Although there were errors due to their native language interference which is the Malay language but a higher percentage $(77.13 \%)$ of the errors were intralingual errors. Our finding is supported by Ponmani and Mekala (2016) who concluded that intralingual errors had more impact on their students' application of English grammatical rules in writing. Similarly, Maniam and Rajagopal (2016) state that the students in their error-analysis study committed grammatical errors due to their lack of knowledge when applying rules of English grammar.

\section{Conclusion}

The data present nine types of grammatical errors made by ESL learners including errors in noun, pronoun, verb, adjective, adverb, article, determiner, preposition and conjunction. Based on the results of this study, grammatical errors were found to occur enormously in ESL learners' writing. Secondly, it is revealed that verb and noun errors were most common while the least were determiner errors. Although errors are inevitable among learners, these findings cogently confirm that the learners have a poor command of written English. Interestingly, Phuket and Othman (2015) stress that the errors made by the learners can inform teachers of their language learning progress. Hence, there is a need for teachers or instructors to pay attention to the most serious problems because solving the serious ones will accelerate students' progress in language learning. However, identification of language errors will be inadequate if no treatment is provided to support students' writing performance. Thus, class instructions should be reinforced with supplementary writing practices (Javed, Juan, \& Nazli, 2013) to expose students to various types of writing in which students can apply their ESL knowledge in the writing exercises.

ESL teachers also need to integrate technology in the writing class to increase students' engagement in writing activities, for example, by developing mobile-assisted grammar practices which students can relate to their ESL writing development. This form of mobile-assisted learning does not only provide an entertaining learning atmosphere (Jin, 2014) but it also boosts learning motivation, provides a practical avenue to incorporate grammar input into learning, and helps teachers attain numerous teaching objectives (Zarzycka-Piskorz, 2016). Furthermore, mobile applications have been perceived as effective in increasing students' awareness of their own language errors and the errors made by their peers (Li \& Hegelheimer, 2013). In conclusion, ESL teachers should focus on students' English 
grammar proficiency particularly in their writing performance. Although students may only produce a minimal number of errors in each of their written assessments, it may engender egregious grammatical errors which will affect their production of written discourses which could also indicate overall teaching quality. Beason (2001) concludes that errors can hamper meaning and portray a negative image of a writer and organization.

\section{References}

Abushihab, I. (2014). An analysis of grammatical errors in writing made by Turkish learners of English as a foreign language. International Journal of Linguistics, 6(4), 213-223. https://doi.org/10.5296/ijl.v6i4.6190

Alhaisoni, M. (2012). An analysis of article errors among Saudi female EFL students: A case study. Asian Social Science-Canadian Center of Science and Education, 8(12), 55-66. https://doi.org/10.5539/ass.v8n12p55

Al-Sawalha, A., \& Chow, T. (2012). The effects of proficiency on the writing process of Jordanian EFL university students. Academic Research International, 3(2), 379-388.

Ansaldo, U. (2010). Contact and Asian Varieties of English. In R. Hickey (Ed.), The handbook of language contact (pp. 498-517). West Sussex: Wiley-Blackwell.

Beason, L. (2001). Ethos and error: How business people react to errors. College Composition and Communication, 53(1), 33-64.

Brown, H. D. (1994). Teaching by principles: Interactive language teaching methodology. New York: Prentice Hall Regents.

Brown, H. D. (2000). Principles of language learning and teaching (4 ed.). Boston, MA: Longman.

Chan, S. H., \& Abdullah, A. N. (2004). Exploring affect in ESL writing behaviour. The English Teacher, 12.

Corder, S. P. (1967). Error analysis and interlanguage. Oxford: Oxford University Press.

Corder, S. P. (1967). The significance of learner's errors. International Review of Applied Linguistics, 5(4), 161-170. https://doi.org/10.1515/iral.1967.5.1-4.161

Corder, S. P. (1974). Error analysis. In J. Allen \& S. Corder (Eds.): The Edinburgh course in applied linguistics Volume 3: Techniques in applied linguistics (pp. 122-154). Oxford: Oxford University Press.

David, A. R., Azman, H., \& Tan, S. M. (2018). Investigating online dialogue journal writing impacts on low proficiency students' writing anxiety. International Journal of Language Education and Applied Linguistics, 71-81.

Etikan, I., Musa, S. A., \& Alkassim, R. S. (2016). Comparison of convenience sampling and purposive sampling. American Journal of Theoretical and Applied Statistics, 5(1), 1-4.

Ghabool, N., Maridass, M. A., \& Kashef, S. H. (2012). Investigating Malaysian ESL students' writing problems on conventions, punctuation, and language use at secondary school level. Journal of Studies in Education, 2(3), 130-143. https://doi.org/10.5296/jse.v2i3.1892 
Gustilo, L., \& Magno, C. (2015). Explaining L2 writing performance through a chain of predictors: A SEM approach. The Southeast Asian Journal of English Language Studies, 21(2), 115-130.

Heydari, P. \& Bagheri, M. S. (2012). Error analysis: Sources of 12 learners' errors. Theory and Practice in Language Studies, 2(8), 1583-1589.

Huang, S. J. (2006). A case study of EFL students' writing errors on a web-based writing program. Paper presented at the International Conference \& Workshop on TEFL and Applied Linguistics, Ming Chuan University.

Ismail, N., Elias, S., Albakri, I. S. M. A., Perumal, P. D., \& Muthusamy, I. (2010). Exploring ESL students' apprehension level and attitude towards academic writing. International Journal of Learning, 17(6).

Javed, M., Juan, W. X., \& Nazli, S. (2013). A study of students' assessment in writing skills of the English language. International Journal of Instruction, 6(2), 129144.

Jin, S. H. Implementation of Smartphone-Based Blended Learning in an EFL Undergraduate Grammar Course. Multimedia-Assisted Language Learning, 17(4), 11-37.

Karim, N. S., Onn., F. M., Musa, H., \& Mahmood, A. H. (2009). Tatabahasa Dewan. (Edisi Ketiga). Kuala Lumpur: Dewan Bahasa dan Pustaka.

Kaweera, C. (2013). Writing Error: A Review of Interlingual and Intralingual Interference in EFL Context. English language teaching, 6(7), 9-18.

Kim, S. (2001). An error analysis of college students' writing: Is that really Konglish?. Studies in Modern Grammar, 25, 159- 174.

Lado, R. (1957). Linguistics across Cultures: Applied Linguistics for Language Teachers. Ann Arbor: University of Michigan Press.

Larsen-Freeman, D., \& Celce-Murcia, M. (1999). The grammar book. Boston, MA Heinle and Heinle.

Li, Z., \& Hegelheimer, V. (2013). Mobile-assisted grammar exercises: Effects on selfediting in L2 writing. Language Learning \& Technology, 17(3), 135-156.

Maniam, M., \& Rajagopal, P. (2016). Simple past tense errors based on surface structure taxonomy in ESL Malaysian undergraduates writing. Global Journal of Advanced Research, 3(6), 547-553.

Marlyna, Maros., Tan, K. H., \& Khazriyati, S. (2007). Interference in learning English: Grammatical errors in English essay writing among rural Malay secondary school students in Malaysia. Jurnal e-Bangi, 2(2), 1-15.

Mohideen, H. (1996). Error analysis - Contributory factors to students' errors, with special reference to errors in written English. The English Teacher Volume XXV.

Nayan, S., \& Jusoff, K. (2009). A study of subject-verb agreement: From novice writers to expert writers. International Education Studies, 2(3), 190-194. https://doi.org/10.5539/ies.v2n3p190

Nunan, D. (1999). Second language teaching and learning. USA: Heinle \& Heinle Publishers.

Pae, T. (2018). Effects of task type and L2 proficiency on the relationship between L1 and $L 2$ in reading and writing: An SEM Approach. Studies in Second Language Acquisition, 40(1), 63-90. doi:10.1017/\$0272263116000462 
Phuket, P. R. N., \& Othman, N. B. (2015). Understanding EFL students' errors in writing. Journal of Education and Practice, 6(32), 99-106.

Ponmani, M., \& Mekala, S. (2016). An analysis of concord errors in ESL learners' writing. The Global Journal of English Studies, 2(1), 1-8.

Putri, P. S., \& Dewanti, A. (2014). An analysis of grammatical errors in writing narrative texts done by the second semester students at the diploma program English Department in Airlangga University Surabaya. Anglicist, 3(1), 1-7.

Ringbom, $\mathrm{H}$. (1987). The role of first language in foreign language learning. USA: Multilingual Matters, Ltd.

Richards, J. C. (1971). A non-contrastive approach to error analysis. English Language Teaching Journal, 25, 204-219.

Richards, J. C. (1974). Error analysis: Perspectives on second language acquisition. London: Longman.

Sattayatham, A., \& Honsa, S. (2007). Medical students' most frequent errors at Mahidol University, Thailand. Asian EFL Journal, 9(2), 170-194.

Seaton, A. \& Fergusson, R. (2010). Grammar plus. Singapore: Learners Publishing.

Selinker, L. (1974). Interlanguage. In J. Richards (Ed.), Error analysis: Perspectives on second language acquisition (pp. 31-54). Essex: Longman.

Singh, C. K. S., Singh, A. K. J., Razak, N. Q. A., \& Ravinthar, T. (2017). Grammar errors made by ESL tertiary students in writing. English Language Teaching, 10(5), 16. https://doi.org/10.5539/elt.v10n5p16

Smith, S., \& Wang, S. (2013). Reading and grammar learning through mobile phones. Language Learning \& Technology, 17(3), 117-134.

Sovakandan, H., Jaganathan, P., \& Husain, F. M. (2018). Investigating low proficiency ESL students' perception of the use of i-Think Maps in writing practices. Malaysian Journal of ELT Research, 14(2), 1-13.

Subramaniam, R., \& Khan, M. H. (2016). Explicit grammar instruction in communicative language teaching: A study of the use of quantifiers. Malaysian Journal of ELT Research, 9(1), 43-73.

Vahdatinejad, S. (2008). Students' error analysis and attitude towards teacher feedback using a selected software: A case study. Unpublished Master Thesis, Universiti Kebangsaan Malaysia.

Vásquez, L. D. A. (2008). Error analysis in a written composition. Profile, 10(1), 135146.

Watcharapunyawong, S., \& Usaha, S. (2012). Thai EFL students' writing errors in different text types: The interference of the first language. English Language Teaching, 6(1), 67-78. https://doi.org/10.5539/elt.v6n1p67

Zarzycka-Piskorz, E. (2016). Kahoot it or not? Can games be motivating in learning grammar?. Teaching English with Technology, 16(3), 17-36. 